\title{
Biological therapies in psoriasis - revisited
}

\author{
MARIA-ISABELA SÂRBU ${ }^{1}$, SIMONA-ROXANA GEORGESCU ${ }^{1,2}$, MIRCEA TAMPA $^{1,2}$, \\ ALEXANDRA-ELENA SÂRBU ${ }^{3}$, OLGA SIMIONESCU ${ }^{1,4}$ \\ "“Carol Davila" University of Medicine and Pharmacy, Bucharest, Romania \\ 2“Victor Babeş" Hospital of Infectious and Tropical Diseases, Dermatology Department, Bucharest, Romania \\ 3"Hexamed" Clinic, Ophthalmology Department, Bucharest, Romania \\ 4،"Colentina" Clinical Hospital, Dermatology Department I, Bucharest, Romania
}

\begin{abstract}
Psoriasis is a chronic, immune mediated disorder affecting approximately $2 \%$ of the population. Even in our days, patients with psoriasis are confronted with stigmatization and social rejection. As a result, their quality of life is significantly impaired. Biological therapies have revolutionized the treatment of moderate to severe psoriasis. The aim of this paper is to look over the most important biological therapies available for the management of plaque-type psoriasis.
\end{abstract}

Key words: psoriasis, biological therapies, TNF- $\alpha$, IL-17, anti-IL-12/23.

\section{INTRODUCTION}

Psoriasis is a chronic, immune-mediated skin disorder with a worldwide occurrence, affecting approximately $2 \%$ of the population. It has a polygenic predisposition. Environmental factors like trauma, infections or medications can trigger the eruption of psoriasis. It is clinically characterized by erythematous, well demarcated plaques covered by silvery-white scales, most often affecting the extensor areas of the extremities, the scalp and the lower lumbosacral area. However, any area can be involved. The disease can occur at any age but two peaks in age of onset were recognised: one between 20 and 30 years and the second between 50 and 60 years. Almost $90 \%$ of patients have plaque-type psoriasis [1-3].

The pathogenesis of psoriasis is not completely understood. It was initially considered an epidermal disease and several mediators like cyclic AMP, protein kinase $\mathrm{C}$, phospholipase $\mathrm{C}$, eicosanoids, transforming growth factor- $\alpha$ (TGF- $\alpha$ ) were incriminated. In recent years however it has been regarded as a T-cell driven disease and the role of lymphocytes and cytokines was intensely studied $[4,5]$. Th1 cells produce IFN $\gamma, \mathrm{TNF} \alpha$ and TNF $\beta$ while Th17 cells produce IL-17, IL-21 and IL-22. IL-17 has an important role in neutrophil chemotaxis and angiogenesis while IL-22 determines hyperproliferation of keratinocytes. IFN $\gamma$ increases the production of IL-23 in dendritic cells which expands Th17 and Th22 cells. TNF $\alpha$ is a pro-inflammatory cytokine which facilitates the entry of inflam- matory cells in the psoriatic plaque by inducing adhesion molecules on vascular endothelial cells. It also stimulates keratinocytes production and activates macrophages and dendritic cells. Other cells also produce cytokines with an important role in the pathogenesis of psoriasis. Therefore, keratinocytes produce IL-8, IL-12, IL-15, IL-18 and TNF $\alpha$ while dendritic cells produce IFN $\alpha$, TNF $\alpha$, IL-20 and IL-23. The interaction of all these cytokines is believed to determine the appearance of the psoriatic plaque $[1,4]$.

The burden of disease is significant in patients with psoriasis. Even in our days, patients with psoriasis are confronted with stigmatization and social rejection. The incidence of mood disorders like depression and anxiety in those patients is higher than in general population. The quality of life is also significantly impaired due to the constant need of treatment, hospitalizations, missed work days, itching and interference with daily activities, among others [6-9].

The treatment of psoriasis has evolved a lot over the years. In $1500 \mathrm{BC}$, before psoriasis was recognized as a separate entity, cat and dog's dung, mixtures of onions, salt and urine or wasp's dung in milk of sycamore were considered appropriate treatments for skin disorders. In the $19^{\text {th }}$ century psoriasis was treated with arsenic, mercury, alkaline salts, phosphorus, thyroid extracts and salicylates [10]. In our days patients with psoriasis have several treatment options for topical or systemic use. Conventional treatments for psoriasis include topical corticosteroids, topical retinoids, vitamin D analogs, dithranol, tars, salicylic acid, phototherapy, 
methotrexate, acitretin and cyclosporine A. Noncompliance to therapy is however often encountered because of the messiness associated with applying topical treatments, the limited efficacy of all agents and the high rate of adverse events. Under those circumstances, the identification of new therapies for psoriasis was of utmost importance [11].

\section{BIOLOGICAL THERAPIES}

Biological therapies revolutionized the treatment of plaque psoriasis. Advances in molecular technology as well as a better understanding of the pathogenic mechanisms in psoriasis allowed the development of more targeted treatments (Table 1).

Table 1

Biological agents for psoriasis [1, 12, 27, 46, 49, 53, 64]

\begin{tabular}{|c|c|c|c|c|}
\hline Class & Drug & Target & Administration & Dosing regimen in psoriasis \\
\hline \multirow[t]{2}{*}{ T-cell modulators } & Alefacept (Amevive ${ }^{\circledR}$ ) & CD2 receptor on T cells & i.m & $\begin{array}{l}15 \mathrm{mg} / \text { week for } 12 \text { weeks. } \\
12 \text { weeks pause. Multiple } \\
12 \text { weeks courses are possible }\end{array}$ \\
\hline & $\begin{array}{l}\text { Efalizumab } \\
(\text { Raptiva®) }\end{array}$ & CD11a subunit of LFA1 & s.c & $1 \mathrm{mg} / \mathrm{kg}$ weekly. \\
\hline \multirow{3}{*}{ TNF antagonists } & $\begin{array}{l}\text { Etanercept } \\
\left(\text { Enbrel }{ }^{\circledR}\right)\end{array}$ & TNF- $\alpha$ & s.c & $25 \mathrm{mg}$ or $50 \mathrm{mg}$ twice weekly \\
\hline & Adalimumab (Humira®) & TNF- $\alpha$ & s.c & $\begin{array}{l}80 \mathrm{mg} \text { loading dose followed } \\
\text { by } 40 \mathrm{mg} \text { every } 2 \text { weeks }\end{array}$ \\
\hline & \begin{tabular}{|l|} 
Infliximab \\
(Remicade $®)$
\end{tabular} & TNF- $\alpha$ & i.v & $\begin{array}{l}5 \mathrm{mg} / \mathrm{kg} \text { at weeks } 0,2,6 \text { and } \\
\text { every } 8 \text { weeks thereafter }\end{array}$ \\
\hline \multirow{3}{*}{ Anti-IL biologic agents } & $\begin{array}{l}\text { Ustekinumab } \\
\left.\text { (Stelara }{ }^{\circledR}\right)\end{array}$ & P40 subunit of IL12 and IL23 & s.c & $\begin{array}{l}45 \mathrm{mg} \text { for patients who } \\
\text { weigh }<100 \mathrm{~kg} \text { and } 90 \mathrm{mg} \text { for } \\
\text { patients who weigh }>100 \mathrm{~kg} \\
\text { at weeks } 0,4 \text { and every } \\
12 \text { weeks thereafter }\end{array}$ \\
\hline & \begin{tabular}{|l|}
$\begin{array}{l}\text { Sekukinumab } \\
\text { (Cosentyx } ®)\end{array}$ \\
\end{tabular} & IL17A & s.c & $\begin{array}{l}300 \mathrm{mg} \text { at weeks } 0,1,2,3,4 \\
\text { and every } 4 \text { weeks thereafter }\end{array}$ \\
\hline & $\begin{array}{l}\text { Ixekizumab } \\
\text { (Taltz®) }\end{array}$ & IL-17A & s.c & $\begin{array}{l}160 \mathrm{mg} \text { at week } 0 ; 80 \mathrm{mg} \text { at } \\
\text { weeks } 2,4,6,8,10,12 \text { and } \\
80 \mathrm{mg} \text { every } 4 \text { weeks thereafter. }\end{array}$ \\
\hline JAK kinase inhibitors & $\begin{array}{l}\text { Tofacitinib } \\
\text { (Xeljanz®/Jakvinus) }\end{array}$ & JAK 1 and JAK 3 inhibitor & oral & $\begin{array}{l}\text { Under investigation for } \\
\text { psoriasis }\end{array}$ \\
\hline $\begin{array}{l}\text { Phosphodiesterase } \\
\text { inhibitors }\end{array}$ & $\begin{array}{l}\text { Apremilast } \\
\left(\text { Otezla }{ }^{\circledR}\right)\end{array}$ & PDE4 & oral & $30 \mathrm{mg} /$ week \\
\hline
\end{tabular}

\section{$T$ cell modulators}

\section{Alefacept}

Alefacept was the first targeted immune modulator specifically designed for the treatment of chronic plaque psoriasis. It was approved by the Food and Drug Administration (FDA) in 2003 for moderate to severe plaque psoriasis. In Europe, it was approved only in Switzerland in 2004.

Alefacept is a human fusion protein composed of the extracellular CD2-binding portion of the human leukocyte function antigen-3 (LFA-3) and the $\mathrm{Fc}$ portion of human IgG1 [2, 11, 12]. It inhibits $\mathrm{T}$ cell activation by binding to the $\mathrm{CD} 2$ receptor on $\mathrm{T}$ lymphocytes and blocking the interaction between LFA-3 expressed on antigen presenting cells and CD2 expressed on T cells. It also induces apoptosis in memory $\mathrm{T}$ cells by binding of the IgG1 portion to the CD 16 receptor of NK cells [1, 11, 13-15].

Alefacept is administered at doses of $15 \mathrm{mg}$ intramuscularly once weekly for 12 weeks followed by a 12 weeks period without treatment. Multiple 12 weeks courses are possible in responders. Studies showed that alefacept was superior to placebo in psoriasis patients. PASI 75 was obtained in approximately $30 \%$ of patients after one course of treatment with alefacept. In the 12 weeks follow-up period $71 \%$ of patients maintained at least PASI 50 . Multiple courses of treatment are associated with better results [2, 16-18].

Studies showed that Alefacept is generally safe and well tolerated. The most frequent side effects are mild headache and injection site inflam- 
mation and pain. Increased transaminase levels and hepatitis were rarely reported. Anti-alefacept antibodies are present in up to $4 \%$ of patients but they are non-neutralizing and were not correlated with adverse reactions $[17,18]$.

In 2011 the promotion and distribution of alefacept was stopped. This event was not related to any safety concerns [15].

\section{Efalizumab}

Efalizumab is a recombinant humanized monoclonal IgG1 antibody directed against CD11a, the alpha subunit of the leukocyte function associated antigen-1 (LFA-1). LFA-1 interacts with intercellular adhesion molecule-1 (ICAM-1) located on antigen presenting cells and endothelial cells thus promoting T-cell activation and migration to the skin. Efalizumab therefore prevents $\mathrm{T}$ cell activation and migration to activation sites which are important steps in the pathogenesis of psoriasis $[2,11,12,19]$.

Efalizumab was approved by the FDA in 2003 for the treatment of moderate to severe plaque psoriasis. In 2004, it was also approved in Europe by the European Medicines Agency (EMA) [11]. Gordon et al. performed a double-blind, placebo controlled trial in which they included 556 patients with moderate to severe psoriasis, 369 of whom received subcutaneous efalizumab and 187 received placebo. The authors found that efalizumab was superior to placebo on all end points. PASI 75 was achieved in $27 \%$ of patients treated with efalizumab and in only $4 \%$ of patients in the placebo group [20].

Efalizumab was administered at doses of $1 \mathrm{mg} / \mathrm{kg}$ weekly for 12 weeks. Patients who achieved at least PASI 50 were candidates to continue the treatment [11].

Efalizumab was voluntarily withdrawn from the market in 2009 in Europe and in the USA after three cases of progressive multifocal leukoencephalopathy (PML) occurred in patients receiving this drug. PML is a fatal demyelinating central nervous system disease caused by the infection with John Cunningham polyomavirus (JCV). This opportunistic infection was previously associated with AIDS and various malignancies. In recent years, it has been linked to immunomodulating therapies like mycophenolate mofetil, rituximab, natalizumab and efalizumab. The psoriatic patients who developed PML had been treated with efalizumab for more than three years. When the drug was taken off the market, more than 46000 patients had received efalizumab [21-23].

\section{TNF- $\alpha$ antagonists}

\section{Etanercept}

Etanercept is a fully human soluble dimeric fusion protein consisting of the extracellular domain of the TNF- $\alpha$ receptor linked to the constant region (Fc) of human IgG1. Etanercept prevents the interaction between TNF- $\alpha$ and its cell surface receptors and therefore inhibits its activity. It was approved in 2004 for the treatment of moderate to severe psoriasis in patients who have not responded to conventional systemic therapies or who have contraindications or do not tolerate those [1, 2, 11, 24].

Etanercept is administered subcutaneously at a dose of $25 \mathrm{mg}$ twice weekly or $50 \mathrm{mg}$ twice weekly for 12 weeks. The maintenance dose is $50 \mathrm{mg}$ weekly or $50 \mathrm{mg}$ twice weekly $[2,11]$.

Leonardi et al. performed a study on 672 patients with chronic plaque psoriasis to evaluate the safety and efficacy of different regimens of etanercept. 652 of those were randomized to receive placebo, low dose etanercept ( $25 \mathrm{mg} /$ week), medium dose etanercept (25 mg twice weekly) or high dose etanercept (50 mg twice weekly). An improvement of $75 \%$, as measured by PASI (PASI75) was found in $4 \%$ of patients receiving placebo, $14 \%$ of patients receiving low dose etanercept, $34 \%$ of patients receiving medium dose etanercept and $49 \%$ of patients receiving high dose etanercept, after 12 weeks of treatment. The authors also found that etanercept was well tolerated [25].

Fernández-Torres et al. performed a study in which they aimed to evaluate the long-term response to etanercept monotherapy in daily practice. The authors included in the study 72 adult patients who achieved an improvement of at least 50\% after 12 weeks of treatment. The authors found that PASI 75 was achieved in $50 \%$ of patients after 3 months, $62.8 \%$ of patients after 6 months, $52.4 \%$ after 12 months, $46.7 \%$ after 24 months, $5.9 \%$ after 36 months and $5.9 \%$ after 42 months. The authors concluded that the maximum response to etanercept treatment is obtained between 6 and 9 months and remains stable in $50 \%$ of patients until 18 24 months [26].

Etanercept is also approved for the treatment of children and adolescents with severe chronic plaque psoriasis from the age of 6 years who failed to respond or are intolerant to conventional treatments. The recommended dose is $0.8 \mathrm{mg} / \mathrm{kg}$ administered weekly (maximum $50 \mathrm{mg}$ per dose) [27]. 
Paller et al. assessed the efficacy and safety of etanercept in children and adolescents aged 4 to 17 years old with psoriasis. 211 patients were initially randomized to receive etanercept or placebo. After 12 weeks $57 \%$ of patients receiving etanercept and $11 \%$ of those in the placebo group achieved PASI 75. All patients were then treated with etanercept for 24 weeks. At week 36, 68\% of patients treated with etanercept and $65 \%$ of patients who initially received placebo achieved PASI 75 . In the last 12 weeks patients were randomly assigned to receive placebo or etanercept. $42 \%$ of patients who received placebo lost the response. $80 \%$ of patients receiving etanercept achieved PASI 75 at week 48. All adverse events resolved without sequelae. The authors concluded that etanercept is efficient in children and adolescents with moderate to severe psoriasis [28].

Studies show that etanercept is relatively safe in the short term [11]. Injection site reactions are the most common adverse events and are usually mild. Upper respiratory tract infections are also more frequent in patients receiving etanercept. Reactivation or primary infection with Mycobacterium tuberculosis is rare $[11,29]$.

Anti-etanercept antibodies were detected in the serum of less than $5 \%$ of patients and they were non-neutralizing; they were not associated with decreased drug response or adverse reactions [29].

\section{Adalimumab}

Adalimumab is a fully human recombinant IgG1 monoclonal antibody targeting TNF- $\alpha$. It binds to both soluble and cell-bound forms of TNF- $\alpha$ thus inhibiting its action. It was approved for the treatment of plaque psoriasis in 2007 [1,2].

Adalimumab is administered subcutaneously at an initial, loading dose of $80 \mathrm{mg}$ and a maintenance dose of $40 \mathrm{mg}$ every two weeks [11].

Gordon et al. showed in a study published in 2006, in which 147 patients with moderate to severe psoriasis were included, that adalimumab was superior to placebo (PASI 75 at week 12 in 53\% of patients who received adalimumab every 2 weeks versus $4 \%$ of patients in the placebo arm) [30]. Menter et al. conducted a randomized, placebo controlled trial in which they aimed to assess the efficacy and safety of adalimumab in continuous versus interrupted therapy. At week 16, $71 \%$ of patients treated with adalimumab and $7 \%$ of those who received placebo achieved PASI 75. Between weeks 16 and 33 all patients who achieved PASI 75 received adalimumab. At week 33, patients who maintained PASI 75 and were initially treated with adalimumab were randomized to receive adalimumab or placebo until week 52 . At week $52,28 \%$ of patients who were re-randomized to placebo and $5 \%$ of patients who received continuous adalimumab treatment failed to achieve adequate response [31]. In 2008 Saurat et al. performed a study in which they aimed to compare the efficacy and safety of adalimumab with that of methotrexate and placebo. At week 16, PASI 75 was achieved by $79.6 \%$ of patients receiving adalimumab, $35.5 \%$ of patients receiving methotrexate and $16.7 \%$ of those receiving placebo. Adverse events were similar in the three groups and the authors concluded that adalimumab was superior to methotrexate and placebo [32].

Papp et al. assessed the efficacy and safety of adalimumab versus methotrexate in children and adolescents with moderate to severe psoriasis. 114 patients were randomized to receive $0.8 \mathrm{mg} / \mathrm{kg}$ adalimumab, $0.4 \mathrm{mg} / \mathrm{kg}$ adalimumab or methotrexate. At week $16,58 \%$ of patients receiving $0.8 \mathrm{mg} / \mathrm{kg}$ adalimumab, $44 \%$ of patients receiving $0.4 \mathrm{mg} / \mathrm{kg}$ adalimumab and $32 \%$ of those receiving methotrexate achieved PASI 75 . The authors concluded that patients who received $0.8 \mathrm{mg} / \mathrm{kg}$ adalimumab obtained significant improvements in PASI 75 as compared to those who received methotrexate [33].

Even though adalimumab is a completely human antibody, anti-drug antibodies have been described in the medical literature and have been associated with loss of efficacy [2]. Carrascosa et al. showed in a study published in 2017 that there is a correlation between drug serum levels and clinical efficacy as measured by PASI score [34].

Adalimumab is generally considered a safe treatment. The most frequently reported adverse event is injection site reaction which occurs in approximately $20 \%$ of patients. Infections are also frequently reported, especially upper respiratory infections and rhinitis. Occasional cases of tuberculosis were also reported. Appropriate screening before starting adalimumab treatment and during treatment is therefore mandatory. Hepatotoxicity, drug induced lupus and lymphoma were also very rarely reported $[2,11,35]$.

\section{Infliximab}

Infliximab is a monoclonal chimeric IgG1 antibody composed of a human antibody constant region and murine variable regions. It targets both soluble and membrane-bound TNF- $\alpha$. It was approved by EMA in 2005 for the treatment of moderate to severe psoriasis $[1,11,15,36]$. 
Infliximab is administered at a dose of $5 \mathrm{mg} / \mathrm{kg}$ body weight as an intravenous infusion over 2 hours at weeks $0,2,6$ and every 8 weeks thereafter $[1,11]$.

The efficacy of infliximab is supported by several studies. Reich et al. performed a doubleblind study in which they aimed to assess the efficacy and safety of infliximab. 378 patients were randomized to receive infliximab $5 \mathrm{mg} / \mathrm{kg}$ or placebo. After 24 weeks, all patients crossed over to infliximab. At week $10,80 \%$ of patients receiving infliximab and $3 \%$ of those in the placebo group achieved PASI 75. The treatment was well tolerated [37]. Menter et al. performed a study on 835 patients with moderate to severe psoriasis to compare the efficacy of continuous and intermittent infliximab maintenance regimens. The patients were randomized to receive $3 \mathrm{mg} / \mathrm{kg}$ infliximab, $5 \mathrm{mg} / \mathrm{kg}$ infliximab or placebo for 14 weeks. At week 14 patients who received infliximab were re-randomized to continuous or intermittent treatment. The authors found a $75 \%$ improvement in $75.5 \%$ of patients receiving $5 \mathrm{mg} / \mathrm{kg}$ infliximab, $70.3 \%$ of patients receiving $3 \mathrm{mg} / \mathrm{kg}$ infliximab and $1.9 \%$ of those in the placebo group, at week 10. At week 50, PASI 75 was achieved in $44 \%$ of patients receiving $3 \mathrm{mg} / \mathrm{kg}$ and $55 \%$ of patients receiving $5 \mathrm{mg} / \mathrm{kg}$ of infliximab in continuous treatment and $25 \%$ of patients receiving $3 \mathrm{mg} / \mathrm{kg}$ and $38 \%$ of patients receiving $5 \mathrm{mg} / \mathrm{kg}$ infliximab in the intermittent group. The authors found that infliximab was generally well tolerated [38].

Infliximab is also associated with a significant improvement in the quality of life. Feldman et al. showed, in a study performed on 249 patients with severe plaque psoriasis, that the quality of life, as measured by Disease Life Quality Index (DLQI), is improved by $84 \%$ in patients receiving $3 \mathrm{mg} / \mathrm{kg}$ infliximab, $91.0 \%$ in patients receiving $5 \mathrm{mg} / \mathrm{kg}$ infliximab and $0 \%$ in patients receiving placebo after 10 weeks of treatment [39].

Since infliximab is a chimeric antibody there is some concern regarding the occurrence of neutralizing anti-infliximab antibodies. These antibodies are associated with lower drug concentrations and the occurrence of adverse drug reactions. The occurrence of anti-infliximab antibodies was reported in disorders like Crohn's disease where it is associated with shorter duration responses but data regarding the appearance of anti-drug antibodies in patients with psoriasis is scarce. Some authors suggest that the combination with low-dose methotrexate improves the long-term efficacy of infliximab. Other authors consider that increasing the dose of infliximab in those patients who stop responding to treatment is more efficient than adding methotrexate $[1,11,12$, $36,40]$.

Infliximab is generally well tolerated. Infusionrelated adverse reactions are encountered in 16$20 \%$ of patients. Autoantibody formation may lead to the development of acute or delayed hypersensitivity reactions. Infections are frequently reported, especially upper respiratory infections. Occasionally infliximab was associated with mycobacterial infections or reactivation of latent tuberculosis. Opportunistic infections like histoplasmosis, aspergillosis, coccidioidomycosis or pneumocystosis were also reported $[1,11,36]$.

\section{Anti-interleukin biologic agents}

\section{a. IL12/IL23 inhibitors}

\section{Ustekinumab}

Ustekinumab is a fully human IgG1 kappa monoclonal antibody directed against the p40 subunit of IL12 and IL23. By preventing IL12 and IL23 to bind to their receptors ustekinumab inhibits the T17 and Th1 signalling pathways $[2,4]$. It was registered in 2009 for the treatment of moderate to severe psoriasis [11].

Ustekinumab is administered subcutaneously at a dose of $45 \mathrm{mg}$ for patients who weigh less than $100 \mathrm{~kg}$ and $90 \mathrm{mg}$ for patients who weigh more than $100 \mathrm{~kg}$, at weeks 0,4 and then every 12 weeks [2].

A randomized, double blind, placebo controlled study performed by Leonardi et al. on 766 patients with moderate to severe psoriasis who were randomized to receive ustekinumab $45 \mathrm{mg}$, ustekinumab $90 \mathrm{mg}$ or placebo found that after 12 weeks of treatment $67.1 \%$ of patients receiving $45 \mathrm{mg}$ ustekinumab, $66.4 \%$ of those receiving $90 \mathrm{mg}$ ustekinumab and $3.1 \%$ of the ones in the placebo group achieved PASI 75. At week 40 patients who maintained an improvement of at least $75 \%$ were re-randomized to maintenance therapy or withdrawal. After 1 year, PASI 75 was better preserved in the group receiving maintenance therapy [41].

Papp et al. performed a double blind, placebocontrolled trial in which they included 1230 patients with moderate to severe psoriasis who were randomized to receive ustekinumab $45 \mathrm{mg}$, ustekinumab $90 \mathrm{mg}$ or placebo. At week $12,66.7 \%$ of patients receiving ustekinumab $45 \mathrm{mg}, 75.7 \%$ of those receiving ustekinumab $90 \mathrm{mg}$ and $3.7 \%$ of those in the placebo group achieved PASI 75. At week 
28 patients who achieved PASI 50 but did not achieve PASI 75 were randomized to continue ustekinumab every 12 weeks or to escalate to ustekinumab every 8 weeks. At week 52, a good response was noticed only in those patients who received ustekinumab $90 \mathrm{mg}$ every 8 weeks [42]. Further studies, in which patients treated with ustekinumab were followed for 5 years, showed no dose related or cumulative toxicity. The authors concluded that exposure for up to 5 years to ustekinumab is safe and effective [43, 44].

A study performed in 2010 by Griffiths et al. compared the efficacy and safety of ustekinumab $45 \mathrm{mg}$ and $90 \mathrm{mg}$ to that of etanercept (50 $\mathrm{mg}$ twice weekly). At week 12, 67.5\% of patients receiving $45 \mathrm{mg}$ of ustekinumab, $73.8 \%$ of those receiving 90 $\mathrm{mg}$ of ustekinumab and $56.8 \%$ of those receiving etanercept achieved PASI 75. The authors concluded that ustekinumab was superior to etanercept with regard to efficacy and has a similar safety profile [45].

Ustekinumab is generally well tolerated. Injection site reactions can occur. Patients must be screened for mycobacterial infection at the beginning of the treatment and every year during treatment. There is an increased risk of myocardial infarction and stroke. Injection site reactions were also reported. Nasopharyngitis and headache were the most common side effects $[2,46]$.

\section{b. IL-17 inhibitors}

\section{Secukinumab}

Secukinumab is a recombinant, fully human IgG1 kappa monoclonal antibody directed against IL-17A. It was approved by the FDA in 2015 for the treatment of moderate to severe psoriasis patients who are candidates for systemic therapy or phototherapy $[47,48]$.

Secukinumab is administered subcutaneously at a dose of $300 \mathrm{mg}$ at weeks $0,1,2,3,4$ and every 4 weeks thereafter [49].

The efficacy and safety of secukinumab in the treatment of psoriasis are supported by several studies. Papp et al. showed in a study published in 2013 that the efficacy of secukinumab $3 \times 75 \mathrm{mg}$ and secukinumab $3 \times 150 \mathrm{mg}$ is superior to placebo [50]. Four multicentre, randomized, double blind, placebo-controlled trials which included 2403 patients with psoriasis had a paramount importance in determining the efficacy and safety of secukinumab: ERASURE, FIXTURE, FEATURE and JUNCTURE. According to these studies, the maximum effect is achieved after 16 weeks of $300 \mathrm{mg}$ secukinumab treatment and is maintained up to 52 weeks. Also, a $50 \%$ improvement is achieved from week 3 [48, $51,52]$.

The most frequent adverse events reported in patients treated with secukinumab are diarrhoea, upper respiratory tract infection, mucocutaneous infections with candida. Pre-treatment evaluation for tuberculosis is mandatory $[49,52]$.

\section{Ixekizumab}

Ixekizumab is a recombinant humanized IgG4 monoclonal antibody which binds with high affinity to IL-17A. It was approved in 2016 by the FDA and EMEA for the treatment of plaque psoriasis in adults who are candidates for systemic therapy [53].

Ixekizumab is administered subcutaneously at a dose of $160 \mathrm{mg}$ at week 0 and $80 \mathrm{mg}$ at weeks $2,4,6,8,10$ and 12 . The maintenance dose is 80 mg every 4 weeks [53].

Three main studies support the efficacy and safety of Ixekizumab in psoriatic patients: UNCOVER-1, UNCOVER-2 and UNCOVER-3. 1296 patients were enrolled in the UNCOVER-1 study. The authors found that after 12 weeks of treatment ixekizumab administered every 2 weeks is superior to ixekizumab administered every 4 weeks and placebo (PASI 75 at week $1289.1 \%$ vs $82.6 \%$ vs 3.9\%). In the UNCOVER-2 study the researchers included 1224 patients who were randomized to receive placebo or ixekizumab $80 \mathrm{mg}$ every 2 weeks or ixekizumab $80 \mathrm{mg}$ every 4 weeks or etanercept $50 \mathrm{mg}$ weekly for 12 weeks. The authors found that ixekizumab administered every 2 weeks was superior to ustekinumab every 4 weeks, etanercept and placebo (PASI 75 at week $1289.7 \%$ vs $77.5 \%$ vs $41.6 \%$ vs 2.4\%). In the UNCOVER-3 study 1346 patients were included. Superior results were also found for the $80 \mathrm{mg}$ every 2 weeks regimen [53-56].

Gottlieb et al. showed in a study published in 2016 that the efficacy of ixekizumab is similar in patients who received prior treatment with biologicals and naive patients [57].

The most frequent adverse events are nasopharyngitis, upper respiratory tract infection, injectionsite reaction, injection-site erythema and headache [54].

\section{Small molecule inhibitors}

Unlike biologicals, small molecule inhibitors target enzymes within signalling pathways. Several small molecules are being investigated for the treatment of psoriasis [58]. 


\section{Janus kinase inhibitors}

The Janus kinases (JAKs) are cytoplasmic tyrosine kinases which, after activation, phosphorrylate the signal of transducer and activator of transcription (STAT) proteins. This leads to transportation of the proteins in the nucleus to regulate gene expression. The JAK-STAT pathway is used by several cytokines to transmit signals to the nucleus. IL-12 and IL-23 are two very important cytokines in the pathogenesis of psoriasis which depend on the JAK-STAT pathway [59, 60].

Tofacitinib is a JAK1 and JAK 3 inhibitor which has been approved by the FDA for the treatment of rheumatoid arthritis. It is being investtigated for the treatment of psoriasis, alopecia areata, atopic dermatitis, and vitiligo, among others [60]. Papp et al. showed in two randomized, placebocontrolled studies (OPT Pivotal 1 and OPT Pivotal 2) that oral tofacitinib $5 \mathrm{mg}$ twice daily and $10 \mathrm{mg}$ twice daily is significantly more efficient than placebo after 16 weeks of treatment [61]. Bachelez et al. aimed to compare the efficacy of tofacitinib $5 \mathrm{mg}$ twice daily and $10 \mathrm{mg}$ twice daily with that of etanercept $50 \mathrm{mg}$ twice weekly and placebo. At week 12, the authors found a $75 \%$ reduction in PASI in $39.5 \%$ of patients receiving $5 \mathrm{mg}$ twice daily tofacitinib, $63.6 \%$ of those receiving $10 \mathrm{mg}$ twice daily tofacitinib, $58.8 \%$ of patients receiving etanercept and $5.6 \%$ of patients receiving placebo. The authors concluded that tofacitinib $10 \mathrm{mg}$ twice daily is non-inferior to etanercept [62].

Baricitinib and ruxolitinib are JAK1/2 inhibitors which are currently being investigated for the treatment of psoriasis. Topical tofacitinib and ruxolitinib were also tested in psoriatic patients with some good results but further studies are necessary to support their efficacy $[59,60,63]$.

\section{Phosphodiesterase inhibitors}

\section{Apremilast}

Apremilast is an inhibitor of phosphodiesterase 4 (PDE4), an enzyme which has an important role in degrading cyclic adenosine monophosphate (cAMP) in inflammatory cells. By inhibiting PDA4, apremilast induces elevated levels of cAMP which decreases T-cell secretion of cytokines like TNF- $\alpha$, INF- $\gamma$, IL-17 and IL-23 [58, 64].

Apremilast was approved for the treatment of moderate to severe psoriasis and psoriatic arthritis. It is administered orally, at a dose of $30 \mathrm{mg}$ twice daily [64].

The ESTEEM 1 trial included 844 patients with moderate to severe psoriasis who were ran- domized to receive apremilast $30 \mathrm{mg}$ administered twice daily or placebo. After 16 weeks of treatment, $33.1 \%$ of patients treated with apremilast and 5.3\% of those receiving placebo achieved PASI 75 [65].

Some authors propose administering apremilast after the failure of conventional systemic therapy and before biological treatments to reduce treatment costs [66].

\section{Biosimilars}

According to the EMA, a biosimilar is a biological medicine highly similar to another already approved biological medicine [67]. Biosimilars are produced after the expiry of the patent of the original product. Biosimilars for infliximab and etanercept are already available for the treatment of moderate to severe psoriasis [68].

Biological therapies have revolutionized the treatment of moderate to severe psoriasis. However, the costs of the treatment are very high and represent a real economic burden for the National Healthcare Systems. Biosimilars are intended to bring the same benefits at a lower price. There was, however, some concern regarding the efficacy and safety of these drugs. Unlike generics, biosimilars have a high molecular weight and a very complex structure. Therefore, even if the amino acid sequence is identical, changes in the tertiary and quaternary structure might affect the efficacy and safety of the drug. On the other hand, different batches of the same reference product are also not identical. Medical agencies have established strict guidelines for the authorization of biosimilars to ensure the safety of those treatments [68-71].

Few studies were done with biosimilars in psoriasis vulgaris but the data available so far supports the safety and efficacy of the products [72-74].

\section{CONCLUSION}

Psoriasis is a common disorder with a great impact on the patient's quality of life. Biological therapies have revolutionized the treatment of moderate to severe psoriasis. The data available so far shows that most of these treatments have an acceptable safety profile. Long-term treatment however seems to be associated with a decrease in efficacy. New therapies, which target different molecules involved in the pathogenesis of psoriasis are therefore currently being investigated.

Conflict of Interest disclosure: The authors declare that there are not conflicts of interest. 
Psoriazisul este o boală cronică, mediată imun, care afectează aproximativ $2 \%$ din populație. Chiar şi în zilele noastre pacienții cu psoriazis se confruntă cu stigmatizarea şi respingerea socială. Drept urmare, calitatea vieții lor este semnificativ deteriorată. Terapiile biologice au revoluționat tratamentul psoriazisului vulgar moderat-sever. Această lucrare $\hat{\imath} s ̧ i$ propune să treacă în revistă principalele terapii biologice disponibile pentru tratamentul psoriazisului în plăci.

Correspondence to: Simona-Roxana Georgescu, $\mathrm{MD}, \mathrm{PhD}$

"Victor Babeş" Hospital, Mihai Bravu Blvd., no. 281-283, $3^{\text {rd }}$ District, Bucharest.

Email: simonaroxanageorgescu@yahoo.com

\section{REFERENCES}

1. LOWELL A. GOLDSMITH, STEPHEN I. KATZ, BARBARA A. GILCHREST, et al. Fitzpatrick's Dermatology in General Medicine, $8^{\text {th }}$ Ed., McGrawHill, 2012.

2. BOLOGNIA JEAN L, JOSEPH L. JORIZZO, SCHAFFER JULIE V. Dermatology. Elsevier, 3 Ed, 2012.

3. BRAUN-FAlCO O., PleWIG G, WOLFF HH, M. LANDTHALER. Braun-Falco's Dermatology. Third edition. Springer. 2009.

4. MAHIL SK, CAPON F, BARKER JN. Update on psoriasis immunopathogenesis and targeted immunotherapy. In: Seminars in immunopathology (Vol. 38, No. 1, pp. 11-27). Springer, Berlin, Heidelberg, 2016.

5. TAMPA M, NICOLAE IL, ENE CD, et al. Vitamin C and Thiobarbituric Acid Reactive Substances (TBARS) in Psoriasis Vulgaris Related to Psoriasis Area Severity Index (PASI). REVISTA DE CHIMIE. 2017; 68(1):43-7.

6. ŁAKUTA P, MARCINKIEWICZ K, BERGLER-CZOP B, et al. How does stigma affect people with psoriasis? Advances in Dermatology and Allergology/Postẹpy Dermatologii i Alergologii. 2017; 34(1):36.

7. OWCZAREK K, JAWORSKI M. Quality of life and severity of skin changes in the dynamics of psoriasis. Advances in Dermatology and Allergology/Postẹpy Dermatologii i Alergologii. 2016; 33(2):102.

8. MANTOVANI L, MEDAGLIA M, PIACENTINI P, et al. Burden of Moderate-to-Severe Plaque Psoriasis and New Therapeutic Approaches (Secukinumab): An Italian Perspective. Dermatology and therapy. 2016; 6(2):151-67.

9. GHORBANIBIRGANI A, FALLAHI-KHOSHKNAB M, ZAREA K, et al. The Lived Experience of Psoriasis Patients from Social Stigma and Rejection: A Qualitative Study. Iranian Red Crescent Medical Journal. 2016; 18(7).

10. BAKER BS. From arsenic to biologicals: a 200 year history of psoriasis. Garner Press; 2008.

11. PATHIRANA D, ORMEROD AD, SAIAG P, et al. European S3-Guidelines on the systemic treatment of psoriasis vulgaris. Journal of the European Academy of Dermatology and Venereology. 2009; 23(s2):1-70.

12. TONY BURNS, STEPHEN BREATHNACH, NEIL COX, et al. Rook's textbook of dermatology. Eighth Edition, Wiley Blackwell, 2010.

13. ZAIDI A, MENG Q, POPKIN D. Can we repurpose FDA-approved alefacept to diminish the HIV reservoir? Immunotherapy (Los Angeles, Calif.). 2015; 1(1).

14. DUNN LK, FELDMAN SR. Alefacept treatment for chronic plaque psoriasis. Skin Therapy Lett. 2010; 15(4):1-3.

15. KAFFENBERGER BH, KAFFENBERGER TM, WONG HK. Immunotargeting in the management of psoriasis. Immuno Targets and Therapy. 2013; 2:51.

16. ELLIS CN, KRUEGER GG. Treatment of chronic plaque psoriasis by selective targeting of memory effector T lymphocytes. New England Journal of Medicine. 2001; 345(4):248-55.

17. SIVAMANI RK, CORREA G, ONO Y, et al. Biological therapy of psoriasis. Indian journal of dermatology. $2010 ; \mathbf{5 5}(2): 161$.

18. LEBWOHL M, CHRISTOPHERS E, LANGLEY R, et al. An international, randomized, double-blind, placebo-controlled phase 3 trial of intramuscular alefacept in patients with chronic plaque psoriasis. Archives of dermatology. 2003; 139(6):719-27.

19. WCISŁO-DZIADECKA D, ZBICIAK M, BRZEZIŃSKA-WCISŁO L, et al. Anti-cytokine therapy for psoriasis-not only TNF- $\alpha$ blockers. Overview of reports on the effectiveness of therapy with IL-12/IL-23 and T and B lymphocyte inhibitors. Advances in Hygiene \& Experimental Medicine/Postepy Higieny i Medycyny Doswiadczalnej. 2016; 70.

20. GORDON KB, PAPP KA, HAMILTON TK, et al. Efalizumab Study Group. Efalizumab for patients with moderate to severe plaque psoriasis: a randomized controlled trial. Jama. 2003; 290(23):3073-80.

21. WHARTON JR KA, QUIGLEY C, THEMELES M, et al. JC polyomavirus abundance and distribution in progressive multifocal leukoencephalopathy (PML) brain tissue implicates myelin sheath in intracerebral dissemination of infection. PloS one. 2016; 11(5):e0155897.

22. SCHWAB N, ULZHEIMER JC, FOX RJ, et al. Fatal PML associated with efalizumab therapy. Insights into integrin $\alpha L \beta 2$ in JC virus control. Neurology. 2012; 78(7):458-67.

23. TAVAZZI E, FERRANTE P, KHALILI K. Progressive multifocal leukoencephalopathy: an unexpected complication of modern therapeutic monoclonal antibody therapies. Clinical Microbiology and Infection. 2011; 17(12):1776-80.

24. TAN JK, APHALE A, MALAVIYA R, et al. Mechanisms of action of etanercept in psoriasis. In: Journal of Investigative Dermatology Symposium Proceedings 2007 (Vol. 12, No. 1, pp. 38-45). Elsevier.

25. LEONARDI CL, POWERS JL, MATHESON RT, et al. Etanercept as monotherapy in patients with psoriasis. New England Journal of Medicine. 2003; 349(21):2014-22. 
26. FERNÁNDEZ-TORRES RM, PARADELA S, FONSECA E. Long-term response to etanercept monotherapy in moderate to severe psoriasis: assessment in daily practice by the maintenance of low values of PASI and BSA. Journal of Dermatological Treatment. 2014; 25(1):54-6.

27. Summary of product characteristics Enbrel. [Accessed 22.06.2017]. Available at: http://www.ema.europa.eu/docs/en_GB/ document_library/EPAR__Product_Information/human/000262/WC500027361.pdf

28. PALLER AS, SIEGFRIED EC, LAN̄GLEY RG, et al. Etanercept treatment for children and adolescents with plaque psoriasis. New England Journal of Medicine. 2008; 358(3):241-51.

29. CARAZO JL, SANTOS LM, MARTINEZ VO. Safety of Etanercept in Psoriasis. Drug safety. 2006; 29(8):675-85.

30. GORDON KB, LANGLEY RG, LEONARDI C, et al. Clinical response to adalimumab treatment in patients with moderate to severe psoriasis: double-blind, randomized controlled trial and open-label extension study. Journal of the American Academy of Dermatology. 2006; 55(4):598-606.

31. MENTER A, TYRING SK, GORDON K, et al. Adalimumab therapy for moderate to severe psoriasis: a randomized, controlled phase III trial. Journal of the American Academy of Dermatology. 2008; 58(1):106-15.

32. SAURAT JH, STINGL G, DUBERTRET L, et al. Efficacy and safety results from the randomized controlled comparative study of adalimumab vs. methotrexate vs. placebo in patients with psoriasis (CHAMPION). British Journal of Dermatology. 2008; 158(3):558-66.

33. PAPP K, THAÇI D, MARCOUX D, et al. Efficacy and safety of adalimumab every other week versus methotrexate once weekly in children and adolescents with severe chronic plaque psoriasis: a randomised, double-blind, phase 3 trial. The Lancet. 2017.

34. CARRASCOSA CARRILLLO JM, TORO MONTECINOS M, BALLESCÁ LÓPEZ F, et al. Correlation between trough serum levels of Adalimumab and absolute PASI score in a series of patients with psoriasis. Journal of Dermatological Treatment. 2017 Jun 12(just-accepted):1-20.

35. TRACZEWSKI P, RUDNICKA L. Adalimumab in dermatology. British journal of clinical pharmacology. 2008; 66(5):618-25.

36. GALL JS, KALB RE. Infliximab for the treatment of plaque psoriasis. Biologics. 2008; 2(1):115-24.

37. REICH K, NESTLE FO, PAPP K, et al. Infliximab induction and maintenance therapy for moderate-to-severe psoriasis: a phase III, multicentre, double-blind trial. The Lancet. 2005; 366(9494):1367-74.

38. MENTER A, FELDMAN SR, WEINSTEIN GD, et al. A randomized comparison of continuous vs. intermittent infliximab maintenance regimens over 1 year in the treatment of moderate-to-severe plaque psoriasis. Journal of the American Academy of Dermatology. 2007; 56(1):31-e1.

39. FELDMAN SR, GORDON KB, BALA M, et al. Infliximab treatment results in significant improvement in the quality of life of patients with severe psoriasis: A double-blind placebo-controlled trial. British Journal of Dermatology. 2005; 152(5):954-60.

40. TAKAHASHI H, TSUJI H, ISHIDA-YAMAMOTO A, et al. Plasma trough levels of adalimumab and infliximab in terms of clinical efficacy during the treatment of psoriasis. The Journal of dermatology. 2013; 40(1):39-42.

41. LEONARDI CL, KIMBALL AB, PAPP KA, et al. Efficacy and safety of ustekinumab, a human interleukin-12/23 monoclonal antibody, in patients with psoriasis: 76-week results from a randomised, double-blind, placebo-controlled trial (PHOENIX 1). Lancet. 2008;371(9625):1665-74.

42. PAPP KA, LANGLEY RG, LEBWOHL M, et al. Efficacy and safety of ustekinumab, a human interleukin-12/23 monoclonal antibody, in patients with psoriasis: 52-week results from a randomised, double-blind, placebo-controlled trial (PHOENIX 2). Lancet. 2008;371:1675-84.

43. PAPP KA, GRIFFITHS CE, GORDON K, et al. Long-term safety of ustekinumab in patients with moderate-to-severe psoriasis: final results from 5 years of follow-up. British Journal of Dermatology. 2013; 168(4):844-54.

44. LANGLEY RG, LEBWOHL M, KRUEGER GG, et al. Long-term efficacy and safety of ustekinumab, with and without dosing adjustment, in patients with moderate-to-severe psoriasis: results from the PHOENIX 2 study through 5 years of follow-up. British Journal of Dermatology. 2015; 172(5):1371-83.

45. GRIFFITHS CE, STROBER BE, VAN DE KERKHOF P, et al. Comparison of ustekinumab and etanercept for moderate-tosevere psoriasis. New England Journal of Medicine. 2010; 362(2):118-28.

46. Summary of product characteristics Stelara [Accessed 22.06.2017]. Available at: http://www.ema.europa.eu/docs/en_GB/ document_library/ EPAR__Product_Information/human/000958/WC500058513.pdf

47. KOFOED K, SKOV L, ŻA $\bar{A}$ CHARIĀE C. New drugs and treatment targets in psoriasis. Acta dermato-venereologica. 2015; 95(2):133-9.

48. GODSE K. Secukinumab-First in Class Interleukin-17A Inhibitor for the Treatment of Psoriasis. Indian journal of dermatology. 2017; 62(2): 195.

49. Prescribing information Cosentyx [Accessed 22.06.2017]. Available at: https://www.accessdata.fda.gov/drugsatfda_docs/ label/2016/125504s001s002lbl.pdf

50. PAPP KA, LANGLEY RG, SIGURGEIRSSON B, et al. Efficacy and safety of secukinumab in the treatment of moderate-tosevere plaque psoriasis: a randomized, double-blind, placebo-controlled phase II dose-ranging study. British Journal of Dermatology. 2013; 168(2):412-21.

51. LANGLEY RG, ELEWSKI BE, LEBWOHL M, et al. Secukinumab in plaque psoriasis-results of two phase 3 trials. New England Journal of Medicine. 2014; 371(4):326-38.

52. FALA L. Cosentyx (Secukinumab): First IL-17A Antagonist Receives FDA Approval for Moderate-to-Severe Plaque Psoriasis. American Health \& Drug Benefits. 2016; 9(Spec Feature):60.

53. Summary of product characteristics Talz. [Accessed 22.06.2017]. Available at: http://www.ema.europa.eu/docs/en_GB/ document_library/EPAR__Product_Information/human/003943/WC500205804.pdf

54. GORDON KB, BLAUVELT A, PAPP KA, et al. Phase 3 trials of ixekizumab in moderate-to-severe plaque psoriasis. New England Journal of Medicine. 2016; 375(4):345-56. 
55. GRIFFITHS CE, REICH K, LEBWOHL M, et al. Comparison of ixekizumab with etanercept or placebo in moderate-to-severe psoriasis (UNCOVER-2 and UNCOVER-3): results from two phase 3 randomised trials. The Lancet. 2015; 386(9993):541-51.

56. HANLEY TL, YIU ZZ. Role of IL-17 in plaque psoriasis: therapeutic potential of ixekizumab. Therapeutics and clinical risk management. 2017; 13:315.

57. GOTTLIEB AB, LACOUR JP, KORMAN N, et al. Treatment outcomes with ixekizumab in patients with moderate-to-severe psoriasis who have or have not received prior biological therapies: an integrated analysis of two Phase III randomized studies. Journal of the European Academy of Dermatology and Venereology. 2017; 31(4):679-85.

58. GUDJONSSON JE, JOHNSTON A, ELLIS CN. Novel systemic drugs under investigation for the treatment of psoriasis. Journal of the American Academy of Dermatology. 2012; 67(1):139-47.

59. DAMSKY W, KING BA. JAK inhibitors in dermatology: The promise of a new drug class. Journal of the American Academy of Dermatology. 2017.

60. SHREBERK-HASSIDIM R, RAMOT Y, ZLOTOGORSKI A. Janus kinase inhibitors in dermatology: A systematic review. Journal of the American Academy of Dermatology. 2017.

61. PAPP KA, MENTER MA, ABE M, et al. Tofacitinib, an oral Janus kinase inhibitor, for the treatment of chronic plaque psoriasis: results from two randomized, placebo-controlled, phase III trials. British Journal of Dermatology. 2015; 173(4):949-61.

62. BACHELEZ H, VAN DE KERKHOF PC, STROHAL R, KUBANOV A, et al. Tofacitinib versus etanercept or placebo in moderate-to-severe chronic plaque psoriasis: a phase 3 randomised non-inferiority trial. The Lancet. 2015; 386(9993):552-61.

63. PORTS WC, KHAN S, LAN S, et al. A randomized phase 2 a efficacy and safety trial of the topical Janus kinase inhibitor tofacitinib in the treatment of chronic plaque psoriasis. British Journal of Dermatology. 2013; 169(1):137-45.

64. Summary of product characteristics Otezla [Accessed 22.06.2017]. Available at: https://ec.europa.eu/health/documents/ community-register/2015/20150115130395/anx_130395_en.pdf

65. PAPP K, REICH K, LEONARDI CL, et al. Apremilast, an oral phosphodiesterase 4 (PDE4) inhibitor, in patients with moderate to severe plaque psoriasis: results of a phase III, randomized, controlled trial (Efficacy and Safety Trial Evaluating the Effects of Apremilast in Psoriasis [ESTEEM] 1). Journal of the American Academy of Dermatology. 2015; 73(1):37-49.

66. MUGHAL F, BARKER J, CAWSTON H, et al. Cost-effectiveness of apremilast in moderate to severe psoriasis in the Uk. Journal of the American Academy of Dermatology. 2016; 74(5):AB243.

67. European Agency of Medicines: Biosimilars. [Accessed 22.06.2017]. Available at: http://www.ema.europa.eu/ema/index.jsp? curl=pages/medicines/general/general_content_001832.jsp\&mid=WC0b01ac0580bb8fda

68. MAZUR M, OLEK-HRAB K, KARCZEWSKI J, et al. Biosimilars in dermatology. Advances in Dermatology and Allergology/Postẹpy Dermatologii i Alergologii. 2015; 32(5):384.

69. RADTKE MA, AUGUSTIN M. Biosimilars in psoriasis: what can we expect? JDDG: Journal der Deutschen Dermatologischen Gesellschaft. 2014; 12(4):306-12.

70. NAST A, ROSUMECK S, SEIDENSCHNUR K. Biosimilars: a systematic review of published and ongoing clinical trials of antipsoriatics in chronic inflammatory diseases. JDDG: Journal der Deutschen Dermatologischen Gesellschaft. 2015; 13(4):294-300.

71. PUIG L. Biosimilars in psoriasis 2015: what is next? Journal of the European Academy of Dermatology and Venereology. 2016; 30(3):467-9.

72. GRIFFITHS CE, THAÇI D, GERDES S, et al. The EGALITY study: A confirmatory, randomised, double-blind study comparing the efficacy, safety and immunogenicity of GP2015, a proposed etanercept biosimilar, versus the originator product in patients with moderate to severe chronic plaque-type psoriasis. British Journal of Dermatology. 2016.

73. DAPAVO P, VUJIC I, FIERRO MT, et al. The infliximab biosimilar in the treatment of moderate to severe plaque psoriasis. Journal of the American Academy of Dermatology. 2016; 75(4):736-9.

74. TICHY M, KOPOVA R, STERNBERSKY J. First experience with therapy of severe forms of psoriasis with biosimilar infliximab. Journal of the European Academy of Dermatology and Venereology. 2016; 30(3):491-3.

Received November $9^{\text {th }}, 2017$ 